observed after only three days treatment with a small dose of ethinyloestradiol it is possible that this may reflect an alteration in binding constant of thyroxine binding proteins rather than a quantitative change. The rapidity with which urinary T-4 returns to basal levels is probably due to the negative feedback control mechanism of the pituitary-thyroid axis whereby circulating levels of the free T-4 influence the release of thyrotrophin. Other possible explanations for these findings include alteration of the hepatic metabolism of $\mathrm{T}-4$ after oestrogen withdrawal, which might account for, or contribute to, the increase in urinary $\mathrm{T}-4$ excretion.

A short course of treatment with ethinyloestradiol did not produce any significant effect on the routine serum thyroid function tests used, although pronounced changes in urinary T-4 excretion were observed. This reflects the sensitivity of the urine T-4 assay. Continued investigation of this thyroidovarian inter-relation is required. Studies of the effects of increased circulating free $\mathrm{T}-4$ on sex hormone binding capacity and of oestrogen therapy on serum thyroid stimulating hormone levels may help in this respect.

We thank Dr. A. Richens for his help in the phenytoin studies, and the Board of Governors, St. Bartholomew's Hospital, for financial support for this project.

Requests for reprints should be sent to: Professor J. Landon, St. Bartholomew's Hospital, London EC1A 7BE.

\section{References}

Arango, G., Mayberry, W. E., Hockert, T. J., and Elveback, L. R. (1968). Proceedings of the Staff Meetings of the Mayo Clinic, 43, 503.

Boccabella, A. V., and Alger, E. A. (1964). Endocrinology, 74, 680.

Chan, V., and Landon, J. (1972). L Lancet, $1,4$.

Chan, V., McAlister, J., and Landon, J. (1972). Fournal of Clinical Pathology, $25,30$.

Clark, F., and Horn, D. B. (1965). Fournal of Clinical Endocrinology and Metabolism, 25, 39.

Dowling, J. T., Freinkel, N., and Ingbar, S. H. (1956). Fournal of Clinical Endocrinology and Metabolism, 16, 1491

Engbring, N. H., and Engstrom, W. W. (1959). Fournal of Clinical Endocrinology and Metabolism, 19, 783.

Engstrom, W. W., Markardt, B., and Leibman, A. (1952). Proceedings of the Society for Experimental Biology and Medicine, 81, 582 .

Fang, V. S., and Selenkow, H. A. (1970). Clinical Chemistry, 16, 185.

Fisher, J. S., and D'angelo, S. A. (1971). Endocrinology, 88, 687.

Florsheim, W. H., and Faircloth, M. A. (1964). Proceedings of the Society for Experimental Biology and Medicine, 117, 56.

Galton, V. A. (1971). Endocrinology, 88, 976.

Heinemann, M., Johnson, C. E., and Man, E. B. (1948). fournal of Clinical Investigation, 27, 91.

Hollander, C. S., Garcia, A. M., Sturgis, S. H., and Selenkow, H. A. (1963). New England Fournal of Medicine, 269, 501 .

Hotelling, D. R., and Sherwood, L. M. (1971). Fournal of Clinical Endocrinology and Metabolism, 33, 783.

Kennedy, G. C., Salaman, D. F., and Hague, P. (1964). Fournal of Endocrinology, 29, 97.

Malkasian, G. D., and Mayberry, W. E. (1970). American fournal of Obstetrics and Gynecology, 108, 1234.

Rosenbaum, J. M., Kreig, A. F., Henry, J. B., Mozley, J. M., and McAfee, J. G. (1968). American fournal of Clinical Pathology, 50, 336.

Tata, J. R. (1960). British Medical Bulletin, 16, 142.

Winikoff, D., and Taylor, K. (1966). Medical fournal of Australia, 2, 108.

\title{
Prevalence of Antibody to Current Influenza Viruses and Effect of Vaccination on Antibody Response
}

\author{
MARGUERITE S. PEREIRA， PRATIMA CHAKRAVERTY， G. C. SCHILD， MARION T. COLEMAN, \\ W. R. DOWDLE
}

British Medical fournal, 1972, 4, 701-703

\section{Summary}

The extent of antibody to the influenza virus $A / H o n g$ Kong/68 (H3N2) after four years of prevalence was investigated in Britain and in the U.S.A. The results indicated a high incidence in both populations. The prevalence of antibody to a variant $A /$ England/42/72 (H3N2) which has been causing epidemics of influenza in the southern hemisphere during the middle months of 1972 was also investigated. The differences reflect the shift in antigenic content of this variant, and although the overall proportion of the sera with antibody at $\geqslant 1 / 40$ was $37 \%$, some age groups had an incidence of only $20 \%$ or less with antibody at this level. A commercial inactivated $A / H o n g$ Kong/68 influenza vaccine was given to a group of volunteers in Britain to see how effective it might be in stimulating antibody to the variant $A /$ England $/ 42 / 72$. The antibody responses were better than expected from ear-

\footnotetext{
Virus Reference Laboratory, Central Public Health Laboratory, London NW9 5HT

MARGUERITE S. PEREIRA, M.D., Director of Virus Reference Laboratory

PRATIMA CHAKRAVERTY, B.SC., M.PHIL., Member of Scientific Staff

W.H.O. World Influenza Centre, National Institute for Medical Research, London NW7 1AA

G. C. SCHILD, B.SC., PH.D. Director of World Influenza Centre

W.H.O. International Influenza Centre for the Americas, Centre for Disease Control, Health Services and Mental Health Administration, Public Health Service, U.S. Department of

Health, Education, and Welfare, Atlanta, Georgia 30333, U.S.A. MARION T. COLEMAN, PH.D., Member of Scientific Staff W. R. DOWDLE, PH.D., Member of Scientific Staff
}

lier vaccine studies, and $63 \%$ of the vaccinees developed antibody to the $A /$ England/42/72 to levels thought likely to be protective. This suggested that until a vaccine made with the variant $A /$ England $/ 42 / 72$ becomes available the present $A / H o n g$ Kong/68 vaccine would be of use to protect those at special risk this winter.

\section{Introduction}

The appearance of the influenza virus A/Hong Kong/68 (H3N2) in 1968 was followed by extensive winter epidemics in which in Britain about two-thirds of the population acquired antibody to this virus (Miller et al., 1971). The winter of 1970-1 was notable in Britain for the absence of epidemiological indices of influenza prevalence, with no increase in morbidity or mortality rates. This would have been regarded as a non-influenza winter, but it was apparent to laboratory workers that the virus was, none the less, circulating to a small extent, since 50 strains of virus were isolated. During the winter of 1971-2 the virus reappeared, and over 700 strains were isolated from cases all over the country. Because of the extended period during which this occurred only small changes resulted in the epidemiological indices. It seemed probable that after these further two years most people in Britain would have antibody to the A/Hong Kong/68 virus and there were likely to be insufficient susceptibles to allow further epidemics of any size to occur.

In the autumn of 1972 epidemics of influenza were reported in the southern hemisphere associated with strains which were significantly different from the A/Hong Kong/ 68 virus. These strains were found to be similar to one (numbered A/England/42/ 72) that had been isolated from a case of influenza in January 1972 in England and which was the only strain of 752 examined that winter to show altered antigenic characteristics (Schild et al., 1972). It was realized that if this variant strain spread in 
the northern hemisphere the possession of antibody to the A/ Hong Kong/68 virus might not necessarily confer protection against infection with the variant. Nor was it certain how effective the currently available vaccine prepared with $A / H o n g$ Kong/68 virus would be in stimulating antibody to the variant virus.

This report describes our findings on the distribution of antibody to the $A / H o n g ~ K o n g / 68$ virus and to the variant $A /$ England $/ 42 / 72$ and the effect $A / H o n g$ Kong/68 vaccine had on the antibody response to these two viruses.

\section{Materials and Methods}

Sera for the main antibody survey were obtained through the co-operation of directors of five public health laboratories situated in different parts of England. The samples had been received by them during May 1972 for a variety of laboratory tests from people of all ages. Altogether 632 sera were tested. Two smaller collections of sera were also tested. One collection obtained in May 1972 and kindly made available by Dr. T. M. Pollock was from 122 British students who were taking part in another investigation. The other collection was made available by Julia F. Eubanks, Georgia Department of Human Resources, Atlanta. These sera were taken in September 1972 from 125 healthy adults.

Sera for the vaccine study were obtained in October 1972 from 118 members of the staff of the Central Public Health Laboratory Colindale, London. Their ages ranged from 18 to 64 years. This group volunteered to give blood samples before and two weeks after receiving a standard dose of inactivated influenza vaccine containing $400 \mathrm{IU}$ of $\mathrm{A} / \mathrm{Hong}$ Kong/68 virus.

Viruses.-An early egg passage material of both $\mathrm{A} /$ Hong Kong/68 and $A /$ England/42/72 viruses was used in the haemagglutination inhibition (H.I.) tests.

Haemagglutination inhibition tests were done by standard procedures previously described (Pereira et al., 1964).

\section{Results}

The frequency and levels of haemagglutination inhibition antibody titres at different ages to the $\mathrm{A} /$ Hong $\mathrm{Kong} / 68$ virus and to the variant $A /$ England/42/72 are shown in table $I$. The sera were divided into three groups-those with titres of $<1 / 10$, those with titres of between $1 / 10$ and $1 / 20$, and those with titres

TABLE I-Distribution of Antibody Titres in Different Age Groups

\begin{tabular}{|c|c|c|c|c|c|c|c|c|c|c|c|c|c|}
\hline \multirow{3}{*}{$\begin{array}{l}\text { Age in } \\
\text { Years }\end{array}$} & \multirow{3}{*}{$\begin{array}{l}\text { No. of } \\
\text { Sera }\end{array}$} & \multicolumn{6}{|c|}{ H.I. Titre to $\mathrm{A} / \mathrm{HK} / \mathbf{1} / 68$} & \multicolumn{6}{|c|}{ H.I. Titre to A/Eng./42/72 } \\
\hline & & \multicolumn{2}{|c|}{$<10$} & \multicolumn{2}{|c|}{$10-20$} & \multicolumn{2}{|c|}{$\geqslant 40$} & \multicolumn{2}{|c|}{$<10$} & \multicolumn{2}{|c|}{$10-20$} & \multicolumn{2}{|c|}{$\geqslant 40$} \\
\hline & & No. & $\%$ & No. & $\%$ & No. & $\%$ & No. & $\%$ & No. & $\%$ & No. & $\%$ \\
\hline $\begin{array}{cc}0-4 & \ldots \\
5-14 & \cdots \\
15-24 & \cdots \\
25-34 & \cdots \\
35-44 & \cdots \\
45-54 & \ldots \\
\geqslant 55 & \ldots\end{array}$ & $\begin{array}{r}33 \\
87 \\
120 \\
119 \\
120 \\
33 \\
120\end{array}$ & $\begin{array}{r}17 \\
5 \\
8 \\
18 \\
26 \\
6 \\
26\end{array}$ & $\begin{array}{r}51 \\
6 \\
7 \\
15 \\
22 \\
18 \\
22\end{array}$ & $\begin{array}{r}3 \\
7 \\
79 \\
7 \\
14 \\
14 \\
11\end{array}$ & $\begin{array}{r}9 \\
8 \\
16 \\
6 \\
12 \\
9 \\
9\end{array}$ & $\begin{array}{l}13 \\
75 \\
93 \\
94 \\
80 \\
24 \\
83\end{array}$ & $\begin{array}{l}40 \\
86 \\
77 \\
79 \\
66 \\
73 \\
69\end{array}$ & $\begin{array}{l}23 \\
24 \\
24 \\
29 \\
68 \\
19 \\
50\end{array}$ & $\begin{array}{l}70 \\
28 \\
20 \\
24 \\
57 \\
58 \\
42\end{array}$ & $\begin{array}{r}45 \\
15 \\
44 \\
19 \\
32 \\
7 \\
36\end{array}$ & $\begin{array}{l}12 \\
17 \\
37 \\
16 \\
27 \\
21 \\
30\end{array}$ & $\begin{array}{r}6 \\
48 \\
52 \\
71 \\
20 \\
7 \\
34\end{array}$ & $\begin{array}{l}18 \\
55 \\
43 \\
60 \\
16 \\
21 \\
28\end{array}$ \\
\hline Total & 632 & 106 & 17 & 64 & 10 & 462 & 73 & 237 & 38 & 157 & 25 & 238 & 37 \\
\hline
\end{tabular}

of $\geqslant 1 / 40$. The level of $\geqslant 1 / 40$ was chosen from evidence obtained in other studies that it was likely to reflect immunity to infection (Miller et al., 1972).

The proportion of sera without detectable antibody to the A/Hong Kong/68 virus was low in all age groups except the youngest, where over half the sera were without antibody. This pattern is reflected in the results with the A/England/42/72 virus, where $70 \%$ of the sera in this age group had no antibody. All age groups other than the youngest had a high proportion of sera with titres over $1 / 40$ with the $\mathrm{A} /$ Hong Kong/68 virus. Only $17 \%$ had no detectable antibody. In the tests with $\mathrm{A} /$ Eng- land/42/72 the proportion of sera with titres of $\geqslant 1 / 40$ was considerably lower than with the A/Hong Kong/68, and in the group under 5 years and over 35 an average of only $20 \%$ of the sera fell into this category. Over $60 \%$ had no demonstrable antibody. The pattern is shown clearly in fig. 1 , with a sharp
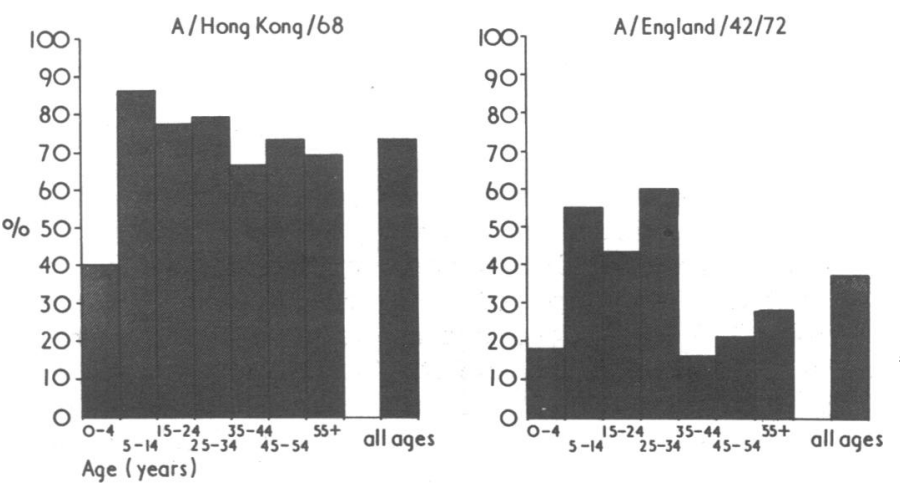

FIG. 1-Age distribution of haemagglutination antibody titre at $\times 40$ to A/Hong Kong/68 and A/England/42/72.

contrast in the proportions with antibody to the two different viruses. Overall the proportion with protective levels of antibody to the $\mathrm{A} / \mathrm{Hong} \mathrm{Kong} / 68$ virus was $73 \%$, whereas only $37 \%$ had corresponding antibody levels to the $A /$ England/42/72 virus.

The results of the haemagglutination inhibition tests on sera from British students were compared with those from American adults (table II). These two groups showed essentially the same high incidence of antibody to the A/Hong Kong/68 virus as was observed in the larger antibody survey. Both groups, however, showed a considerably lower incidence of antibody to the A/England/42/72 virus than was found in the larger survey, and only $10 \%$ had antibody at the $\geqslant 1 / 40$ level.

TABLE II-Comparison of Percentage of Sera with Antibody to A/HongKong/68 and $A /$ England $/ 42 / 72$ Viruses in U.S.A. and U.K.

\begin{tabular}{cc|c|c|c|c}
\hline \multicolumn{2}{c|}{$\begin{array}{c}\text { H.I. } \\
\text { Antibody } \\
\text { Titre }\end{array}$} & \multicolumn{2}{c|}{ U.S.A. } & \multicolumn{2}{c}{ U.K. } \\
\cline { 2 - 6 } & A/H.K./68 & A/Eng./42/72 & A/H.K./68 & A/Eng./42/72 \\
\hline$<10 \ldots$ & $\cdots$ & 3 & 30 & 11 & 51 \\
$10-20$ & $\cdots$ & 23 & 60 & 17 & 38 \\
$\geqslant 40 .$. & $\cdots$ & 74 & 10 & 72 & 11 \\
\hline
\end{tabular}

TABLE III-Haemagglutination Inhibition Antibody Titres 14 Days after A/Hong Kong/68 Vaccine (118 Volunteers)

\begin{tabular}{|c|c|c|c|c|c|c|}
\hline \multirow{2}{*}{ Sera } & \multicolumn{3}{|c|}{$\begin{array}{l}\text { Antibody Titre } \\
\text { to A/Hong Kong/68 }\end{array}$} & \multicolumn{3}{|c|}{$\begin{array}{l}\text { Antibody Titre } \\
\text { to A/England/42/72 }\end{array}$} \\
\hline & $<10$ & $10-20$ & $\geqslant \mathbf{4 0}$ & $<10$ & $10-20$ & $\geqslant 40$ \\
\hline 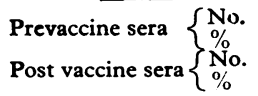 & $\begin{array}{r}12 \\
10 \\
1 \\
1\end{array}$ & $\begin{array}{r}17 \\
14 \\
1 \\
1\end{array}$ & $\begin{array}{r}89 \\
75 \\
116 \\
98\end{array}$ & $\begin{array}{r}48 \\
41 \\
8 \\
7\end{array}$ & $\begin{array}{l}40 \\
34 \\
35 \\
30\end{array}$ & $\begin{array}{l}30 \\
25 \\
75 \\
63\end{array}$ \\
\hline
\end{tabular}

The results of the vaccine study done in October 1972 are shown in table III. The proportions of the prevaccine sera falling into each category of antibody titres were roughly of the same order as those shown in table I for both viruses. The vaccine produced a sharp increase in the number of sera with titres of over $1 / 40$ against the A/Hong Kong/68 virus, with only two of the 118 volunteers remaining with titres below $1 / 40$. The proportion of sera with titres of $\geqslant 1 / 40$ against the variant A/England $/ 42 / 72$ increased from $25 \%$ to $63 \%$.

The distribution of antibody titres before and after vaccination is illustrated in fig. 2. Altogether 76 people $(64 \%)$ had fourfold or greater rises in antibody to the A/Hong Kong/68 virus, and $63(53 \%)$ had fourfold or greater rises to A/England/ 42/72. However, 15 of these 63 responses were from a titre of only $<1 / 10$ to $1 / 20$, which did not bring them into the group considered to have acquired protective levels. 

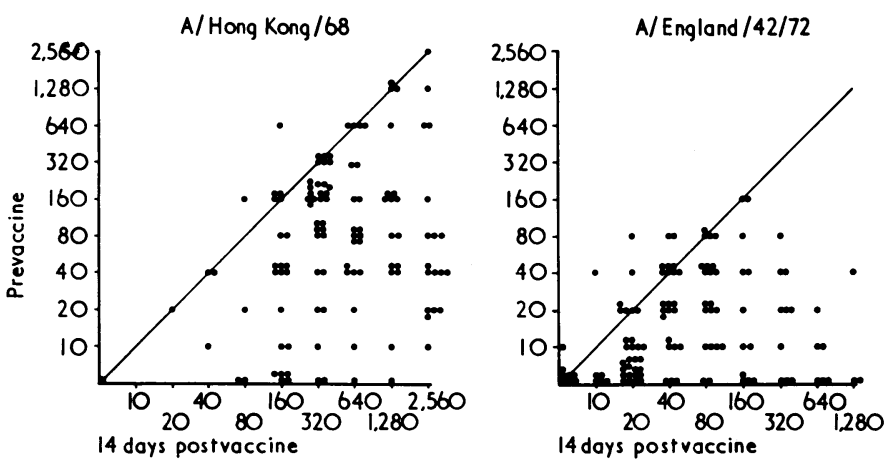

FIG. 2-Haemagglutination inhibition response in 118 people given inactivated A/Hong Kong/68 vaccine.

These results can be compared with some obtained with sera taken during a vaccine study done in the U.S.A. in 1968 before the first $\mathbf{A} /$ Hong Kong/68 epidemic had occurred. In this study A/Hong Kong/68 vaccine was given to 20 people, $90 \%$ of whom produced antibody titres of $\geqslant 1 / 40$ to the homologous virus. However, when the postvaccine sera were tested with $\mathrm{A} /$ Queensland/6/72 virus, which is similar to the A/England/ $42 / 72$ variant, only $10 \%$ had titres of $\geqslant 1 / 40$

\section{Discussion}

Studies of the impact of the A/Hong Kong/68 virus on the population of Britain showed (Miller et al., 1971) that after the first two years of epidemics only about $30 \%$ of the population were without antibody. During the following two years the same virus was detected to a small extent during the winter of 1970-1 and rather more extensively during the winter of 1971-2. The frequency of antibody after these four winters was examined in sera taken during the summer of 1972, and it was found that by this time with all ages averaged only $17^{\circ},{ }^{\prime}$ were without demonstrable antibody. The results were broadly similar to those found with sera taken in September 1972 in the U.S.A. With the appearance of the variant typified by $A /$ England/42/72 it was clearly of importance to see what effect this degree of antigenic difference would have on the antibody pattern.

The results in this study were analysed to separate the sera with titres of $1 / 40$ or more from the rest. The reason for this was based on evidence gathered in other studies (Miller et al., 1972) that this level of antibody appeared to confer protection against infection. When this was done it was found that whereas $73 \%$ of the sera had antibody at $\geqslant 1 / 40$ to the $\mathrm{A} / \mathrm{Hong} \mathrm{Kong} / 68$ virus an average of only $37^{\circ}, \mathrm{o}$ had antibody at these titres to the variant $\mathrm{A} /$ England $/ 42 / 72$, and the proportion in certain selected groups was actually considerably lower. For example, in a small collection of sera from students in England only $11 \%$ had antibody at titres of $\geqslant 1 / 40$, and a similar low proportion $(10 \%)$ was found in a small number of sera from adults in the U.S.A. Thus it became clear that if the variant spread during the winter of 1972-3 the population would be largely unprotected against it. It was therefore of interest to determine whether conventional inactivated influenza vaccines containing A/Hong Kong/68 virus would stimulate antibody to the variant $\mathrm{A} /$ England/42/72.

Results with sera from a small study done in the U.S.A. before the A/Hong Kong/ 68 virus appeared suggested that the response to $\mathrm{A} / \mathrm{Hong} \mathrm{Kong} / 68$ vaccine would induce only a minimal response to the $A /$ England $/ 42 / 72$ virus. However, the vaccine study reported here showed that although the effect was not as good as with the homologous virus, since all but two sera $(98 \%)$ developed antibody to $\mathrm{A} /$ Hong Kong $/ 68$, the response was nevertheless much greater than had been expected, with the proportion of those with antibody to the A/England/42/72 variant increasing from $25^{\circ}{ }_{\circ}$ to $63 \%$ by 14 days after the vaccination. This greatly improved cross-reacting response presumably reflects the presence of a high incidence of considerable titres of $\mathrm{A} / \mathrm{Hong} \mathrm{Kong} / 68$ antibody. These findings suggest that this vaccine will not be ineffective in boosting antibody to the A / England / 42/72 variant and should be used to protect those particularly at risk until influenza vaccines containing the appropriate strain become available. In order to provide potential vaccine strains of $\mathrm{A} /$ England/42/72 virus which produce high virus yields and therefore enhance the rate at which vaccine can be produced, high-yielding recombinant strains (Kilbourne, 1969; McCahon and Schild, 1971) antigenically identical to A/England/42/72 have been produced, and their properties will be described elsewhere (Schild, 1972).

We should like to thank Mr. P. Cunningham for his excellent technical help. The directors of the public health laboratories who sent us sera for testing were: Dr. H. R. Cayton, Bristol; Dr. G. R. E. Naylor, Cambridge; Dr. G. C. Turner, Liverpool; Dr. P. R. Mortimer, Teesside; and Dr. D. J. H. Payne, Portsmouth.

\section{References}

Kilbourne, E. D. (1969). Bulletin of the World Health Organization, 41, 643. McCahon, D., and Schild, G. C. (1971). Fournal of General Virology, 12, 207. Miller, D. L., Pereira, M. S., and Clarke, M. (1971). British Medical fournal, 1,475 .

Miller, D. L., Read, D., Diamond, J., Peveira M. S., and Chakraverty, P. (1972). To be published.

Pereira, H. G., Pereira, M. S., and Law, V. G. (1964). Bulletin of the World Health Organization, 31, 129.

Schild, G. C. (1972). To be published.

Schild, G. C., Pereira, M. S., Chakraverty, P., Coleman, M. T., and Dowdle, W. R. (1972). To be published

\section{Method of Breech Management Incorporating Use of Fetal Blood Sampling}

\section{B. W. ELIOT, J. G. HILL}

British Medical fournal, 1972, 4, 703-706

\section{Summary}

We have developed a method of breech management based on the use of fetal blood sampling. Twenty-five cases were studied throughout labour, and fetal blood samples taken throughout the first and second stages.

\footnotetext{
Department of Obstetrics, Pembury Hospital, Tunbridge Wells, Kent

B. W. ELIOT, M.B., M.R.C.o.G., Registrar

J. G. HILL, F.R.C.S., M.R.C.o.G., Consultant
}

These showed that the Apgar score at one minute correlated closely with the fetal pH just before delivery. We believe that cord compression is an important variable factor which can be assessed only by fetal blood sampling. If this shows that fetal anoxia is becoming severe then immediate delivery is mandatory.

\section{Introduction}

Over the years there has been considerable diversity of opinion regarding the main cause of death in the baby delivered as a 